\title{
Carbon and nitrogen stock and fluxes in coastal Atlantic Forest of southeast Brazil: potential impacts of climate change on biogeochemical functioning
}

\author{
Villela, DM. ${ }^{a *}$, de Mattos, EA. ${ }^{b}$, Pinto, AS. ${ }^{c}$, Vieira, SA. ${ }^{d}$ and Martinelli, LA. ${ }^{e}$ \\ ${ }^{a}$ Laboratório de Ciências Ambientais, Centro de Biociências e Biotecnologia, \\ Universidade Estadual do Norte Fluminense Darcy Ribeiro - UENF, \\ Av. Albero Lamego, 2000, Horto, CEP 28013-620, Campos dos Goytacazes, RJ, Brazil \\ 'Laboratório de Ecologia Vegetal, Departamento de Ecologia, Instituto de Biologia - IB, \\ Universidade Federal do Rio de Janeiro - UFRJ, Ilha do Fundão, CP 68020, CEP 21941-970, Rio de Janeiro, RJ, Brazil \\ 'Laboratório de Ecologia de Ecossistemas, Departamento de Ecologia, Instituto de Biologia, \\ Universidade de Brasília - UnB, Campus Universitário Darcy Ribeiro, CEP 70910-900, Brasília, DF, Brazil \\ ${ }^{d}$ Núcleo de Estudos e Pesquisas Ambientais - NEPAM, Universidade Estadual de Campinas - UNICAMP, \\ Rua dos Flamboyants, 155, Cidade Universitária, CEP 13083-867, Campinas, SP, Brazil

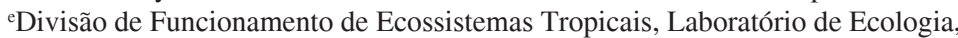 \\ Centro de Energia Nuclear na Agricultura, Universidade de São Paulo - USP, \\ Av. Centenario, 303, São Dimas, CP 96, CEP 13400-000, Piracicaba, SP, Brazil \\ *email: dora@uenf.br
}

Received February 13, 2012 - Accepted February 27, 2012 - Distributed August 31, 2012

\begin{abstract}
The Atlantic Forest is one of the most important biomes of Brazil. Originally covering approximately 1.5 million of $\mathrm{km}^{2}$, today this area has been reduced to $12 \%$ of its original size. Climate changes may alter the structure and the functioning of this tropical forest. Here we explore how increases in temperature and changes in precipitation distribution could affect dynamics of carbon and nitrogen in coastal Atlantic Forest of the southeast region of Brazil The main conclusion of this article is that the coastal Atlantic Forest has high stocks of carbon and nitrogen above ground, and especially, below ground. An increase in temperature may transform these forests from important carbon sinks to carbon sources by increasing loss of carbon and nitrogen to the atmosphere. However, this conclusion should be viewed with caution because it is based on limited information. Therefore, more studies are urgently needed to enable us to make more accurate predictions.
\end{abstract}

Keywords: Atlantic Forest, biogeochemistry, carbon, climatic changes, nitrogen, topography.

\section{Estoques e fluxos de carbono e nitrogênio nas zonas costeiras da Mata Atlântica do sudeste do Brasil: potenciais impactos das mudanças climáticas sobre o funcionamento biogeoquímico}

\begin{abstract}
Resumo
A Mata Atlântica é um dos mais importantes biomas do Brasil. Sua cobertura original estendia-se por aproximadamente 1,5 milhão de $\mathrm{km}^{2}$. Atualmente, sua área ocupa somente $12 \%$ de sua cobertura original. As mudanças climáticas podem alterar a estrutura e o funcionamento dessa floresta tropical. Neste artigo, discute-se como aumentos na temperatura do ar e mudanças na distribuição das chuvas podem afetar a dinâmica do carbono e do nitrogênio na Mata Atlântica litorânea da Região Sudeste brasileira, cuja disponibilidade de informações é maior. A principal conclusão deste artigo é que essas florestas detêm elevados estoques de carbono e nitrogênio acima do solo e, especialmente, abaixo do solo. Um aumento na temperatura do ar pode transformar essas florestas de sumidouros para fontes de carbono para a atmosfera por meio de um aumento nos processos de decomposição. Entretanto, essas conclusões devem ser vistas com cautela já que estão baseadas em um número limitado de informações. Portanto, é urgente que um número maior de informações seja produzido, permitindo conclusões mais robustas no futuro.
\end{abstract}

Palavras-chave: biogeoquímica, carbono, Mata Atlântica, mudanças climáticas, nitrogênio, topografia. 


\section{Introduction}

The Atlantic Forest is considered one of the major tropical biomes in the world. In terms of biodiversity, it is considered an important center of endemism and one of the 25 "hotspots" of the world. Among these, it is considered by some "the hottest of the hotspots" (Cardoso da Silva et al., 2004; Laurance, 2009). This entire biome originally covered approximately 1.5 million $\mathrm{km}^{2}$ spanning a latitudinal range of approximately $28^{\circ}$ and a longitudinal range of approximately $25^{\circ}$. Today, only approximately $12 \%$ remains mainly due to agriculture expansion and urbanization (Ribeiro et al., 2009). Most important is the fact that while this biome is vanishing, we have not yet acquired sufficient knowledge about it to propose sound conservation and regeneration programs that could be transformed into public policy. It is true that in recent decades, biological data on the Atlantic Forest has increased (e.g. Laurance, 2009; Ribeiro et al., 2009; Lôbo et al., 2011). On the other hand, information about the functioning of the forest in terms of its hydrological and biogeochemical cycle is much less available. Most of the data available focuses on coastal and sub coastal forest areas located in the Southeast region of Brazil.

The main objective of this paper is to summarize the available information on the biogeochemical process that regulates the carbon and nitrogen dynamics in the southeastern coastal Atlantic Forest of Brazil. Based on the knowledge that specific environmental conditions, such as climate, soils, species composition and successional stage, drive nutrient cycling in tropical forests (Vitousek, 2004; Saiter et al., 2009), we will focus our analysis on how climate changes according to scenarios described by Marengo et al. (2009), which may affect carbon and nitrogen of the coastal Atlantic Forest. In this context, it is also important to remember that biodiversity of this area can also be severely affected by climate changes (Loiselle et al., 2010).

In the first part of this review, we present the environmental features, namely, precipitation and temperature, as driving forces of changes in nutrient dynamics. This topic is followed by an analysis of how changes in species composition due to climatic changes may interfere with biogeochemical cycles. In the second part of this article we summarise the available information on carbon and nitrogen dynamics. The last part of this article is dedicated to forecasting potential impacts of climate changes on these elements.

\section{Environmental Driving Forces Acting on Carbon and Nitrogen Dynamics in the Atlantic Forest}

\subsection{Effects of precipitation and seasonality on carbon and nitrogen inputs of tropical forests}

It is well known that biogeochemistry cycles are strongly related to rainfall in moist and seasonally dry tropical forests in the opposite manner (Saiter et al., 2009).
Among these processes, litterfall, litter nutrient input, decomposition rates and nutrient release are strongly influenced.

While in moist tropical forests the peak litterfall, than as a consequence $\mathrm{C}, \mathrm{N}$ as other nutrients, is in the wet season, in seasonally dry forests the peak of litterfall mass and nutrient input is in the dry season. This common pattern of tropical forests suggests that water is one of the main factors driving leaf-litterfall and its nutrients in these ecosystems (Brando et al., 2008).

Climate may also interfere with the litter decomposition process, a critical step in biogeochemistry cycling, which is responsible for the transference of nutrients from the litter layer to the poor surface soils of the tropics (Saiter et al., 2009) and carbon and nitrogen release from organic matter. Dry-season retardation of leaf-litter decomposition has been observed in moist (Luizão and Schubart, 1987) and dry tropical forests (Villela et al., 1998; Villela and Proctor, 2002).

Pulses of nutrients are known to be important regulators in tropical forest functioning (Lodge et al. 1994; Villela and Proctor, 2002). Nevertheless, a change in its mechanism should be accompanied by alterations in forest dynamics in terms of population and community growth and processes.

Carbon and $\mathrm{N}$ litter inputs in Atlantic forests follow similar patterns found for tropical forests. This process is very seasonal, driven mainly by leaf-litterfall mass (Villela et al., 2006). In moist tropical forests, the $\mathrm{C}$ and $\mathrm{N}$ peak is in the wet season (Mazurec and Villela, 1998; Moraes et al., 1999; Cavi et al. 2009), while in seasonally dry forests, the peak of litterfall mass and nutrient input is in the dry season, as reported for the Tabuleiro forest (Villela et al., 1998; Villela et al., 2006), as in seasonal Atlantic forests elsewhere (Portela and Santos, 2007). However the annual and seasonal rainfall effect is not clear over the annual quantities of litterfall in Atlantic forests, as moist or dry forests produce annually about 5.5 to $10 \mathrm{Mg} \mathrm{ha}^{-1}$ year $^{-1}$ litter mass (Mazurec and Villela, 1998; Moraes et al. 1999; Villela et al. 1998; Cavi et al. 2009), a variation that may be driven also by other factors such as floristic composition, successional stage or soil type (Saiter et al., 2009). Generalising about $\mathrm{C}$ and $\mathrm{N}$ input can be difficult as data are scarce, mainly in seasonally dry forests.

The seasonal period of nutrient input to the forest floor through the litter is decisive in availability and/or possible risks of nutrient losses, as decomposition and mineralisation processes are greatly related to water availability. Leaflitter decomposition rates and nutrient release is low in seasonal Atlantic forests (Villela et al., 1998) compared to the moist Atlantic forests in the same region of northeast Rio de Janeiro state, as occurs elsewhere in the tropical forests (Saiter et al., 2009).

The faster decomposition process in the wet season is attributed to an increase in the activity of micro-decomposers and macro-fauna, and in some forests to a greater growth of fine roots, caused by water and nutrients availability (Luizão and Schubart, 1987; Saiter et al., 2009). A rapid decomposition rate is the result of the initial rains stimulating 
mass loss and nutrient release after dry spells resulting in pulses of nutrients (Lodge et al., 1994; Saiter et al., 2009).

Therefore, the higher stock of $\mathrm{C}, \mathrm{N}$ and other nutrients in the small litter layer of seasonal Atlantic forests in the dry season may be a consequence of the high input and a low litter decomposition rate during this season (Villela et al., 2006). However, although differences among sites may influence decomposition, the effects of substrate quality and soil fauna can be crucial in this process in tropical forests. This common pattern of tropical forests suggests that water is one of the main factors that drive leaf-litterfall and its nutrients in these ecosystems.

\subsection{Altitude and temperature effects on the Serra do Mar Atlantic Forest}

Altitude is a factor that may interfere with the rain forest structure, productivity, nutrient limitation and cycling. Most studies have shown that tropical rain forests decrease in stature, above-ground biomass and net primary productivity, litterfall nutrient input, decomposition rate, and soil nitrogen concentration, with increasing elevation mainly in response to decreasing temperatures (Saiter et al., 2009). Plant growth and litter production, are limited by $\mathrm{N}$ or $\mathrm{N}$ and $\mathrm{P}$ in montane forests (Kitayama and Aiba, 2002), which may be not only an effect of soil nutrient limitation and reduction of plant nutrients with altitude, but it may be influenced by air temperatures directly (Kitayama and Aiba, 2002). These features are more evident in forests situated above 1500 to $2000 \mathrm{~m}$ asl.

In addition to the latitudinal and longitudinal ranges, the presence of these mountain chains also creates an altitudinal wide range, reaching more than $1000 \mathrm{~m}$ above sea level (asl) at the Serra do Mar and Serra da Bocaína and more than $2000 \mathrm{~m}$ asl at the Serra da Mantiqueira. This altidudinal gradient creates a temperature gradient with lower temperatures at higher altitudes (Sousa Neto et al., 2011). Temperature is one of the most important factors that influences several biogeochemical terrestrial processes (Blankinship et al., 2011; Wu et al., 2011). Therefore, this altitudinal range offers an interesting perspective to investigate potential effects of global changes in basic biogeochemical processes in the coastal Atlantic Forest.

\section{Floristic Composition and Diversity and its Relations to $\mathrm{C}$ and $\mathrm{N}$ Cycling in the Atlantic Forests}

The increase in human exploitation of forest ecosystems has led to marked changes in the availability of resources, pollution, loss and fragmentation of habitats, which has been caused significant loss of species (Vitousek et al., 1997; Novacek and Cleland, 2001; Brook et al., 2003; Tabarelli et al., 2004). In addition to many other problems, land-use changes reduce functional redundancy of plant communities, increasing their vulnerability to future disturbances (Laliberté et al., 2010). The effects of loss of species or changes in diversity of natural communities for the functioning of ecosystems are sometimes contradictory
(Tilman et al., 1997; Kinzig et al., 2002; Loreau et al., 2002; Smith and Knapp, 2003; Bunker et al., 2005; Scherer-Lorenzen, 2007). In general, however, changes in species richness and composition negatively affect population stability and magnitude of fluxes of matter and energy in ecosystems (Chapin et al., 2000; Sala et al., 2000; Bunker et al., 2005; Ruiz-Jaen and Potvin, 2011).

One of the main mechanisms explaining the positive relationships of diversity and species composition with ecosystem processes is associated with the complementary effect of species due to niche differentiation (Naeem et al., 2009). Depending on the functional diversity variation among coexisting species, a more efficient use of resources is expected, as at the same time decreasing interspecific competition, which overall may increase ecosystem productivity (Scherer-Lorenzen et al., 2007). On the other hand, many tropical vegetation types have few species that attain high dominance at the community level, mainly in terms of biomass, in contrast to many subordinate or rare species (Hubbell, 2001; Macía and Svenning, 2005; Pimentel et al., 2007). Thus, one may expect that the higher abundance of a few species will be the main driver of community structure that modulate the magnitude of fluxes of energy and matter in ecosystems (Grime, 1998; Dangles and Malmqvist, 2004). However, some rare species might also contribute disproportionately to the ecosystem processes due to a high level of specialization such as nitrogen fixation (Reed et al., 2008).

One important point to consider is that loss of species due to climate change will not be random. How many and which species will be driven to extinction will depend on the intensity, frequency and duration of changes in environmental factors and also according to the intrinsic abilities of species to deal with stress and disturbances that will be associated with climate change (Vitousek et al., 1997; Grime, 1998; Smith and Knapp, 2003; Bunker et al., 2005). Rare species that are the most diverse component of communities are also the most vulnerable to extinction due to stochastic effects related to small population size (Hubbell, 2001). Thus, the consequences of species loss to ecosystem function will be related to the relative abundance of a species in the community, the specific role of species in ecosystem function and the possible occurrence of compensatory effects of remaining species (Lavorel and Garnier, 2002; Larsen et al., 2005).

Effects of species loss on carbon stocks and fluxes will be largely dependent on intrinsic characteristics of species such as wood density, maximal height and trunk diameter (Ruiz-Jaen and Potvin, 2011) and traits related to the leaf economic spectrum (Lavorel and Garnier, 2002; Wright et al., 2004). In forests with large trees possessing high leaf mass per area, greater potential for carbon storage exists (Ruiz-Jaen and Potvin, 2011). This type of situation is often found in late successional species of mature forests. However, throughout tropical rainforests, the interactions of habitat loss and fragmentation are driving forest remnants to early successional stages (Laurance et al., 2006; Tabarelli et al., 2010) and taxonomic 
homogenisation (Lôbo et al., 2011). In this case, fastgrowing pioneer and generalist species are favored, with clear consequences for nutrient stocks and fluxes. Selective logging in the Tabuleiro forest also had similar effects on decreasing the abundance of large trees and decreasing litterfall and nutrient cycling (Villela et al., 2006). Fastgrowing species tend to have less dense wood and low leaf mass per area (Bunker et al., 2005), decreasing the potential for carbon storage and increasing decomposition rates often associated with leaves with lower $\mathrm{C} / \mathrm{N}$ ratios (Quested et al., 2007). Taxonomic homogenization might affect community responses to climate change depending of the effects on functional diversity. However, generalist species may be able to resist a wide range of environmental conditions, sustaining, despite low nutrient stocks and higher decomposition rates, more stable community biomass and species composition throughout some yet unpredictable level of climate change (Richmond et al., 2005).

\section{Carbon and Nitrogen Stocks}

The two main reservoirs of carbon and nitrogen in an ecosystem are located above and below ground. Above ground reservoirs encompass the trees, palms, ferns, snags, coarse wood debris and litter, while the below ground encompass soil organic matter, and coarse and fine roots. Generally, one-meter depth soil stock is assumed to estimate below ground stocks.

\subsection{Below-ground stocks}

In a study on an altitudinal range from $100 \mathrm{~m}$ to $1000 \mathrm{~m}$ in the Coastal Atlantic Forest located in the northern coast of the State of São Paulo in Ubatuba, Martins et al. (in review) found high carbon and nitrogen stocks in the soil down to $1 \mathrm{~m}$ deep compared with soils in the Amazon region (Table 1). Most interestingly there was a progressive increase in carbon and nitrogen stocks with altitude (Vieira et al., 2011). The carbon stock increased from approximately 190

Table 1. Carbon, nitrogen and phosphorus stocks in different belowground compartments in a Coastal Atlantic Forest, Ubatuba, São Paulo, Brazil.

\begin{tabular}{|c|c|c|c|}
\hline & \multicolumn{3}{|c|}{ Altitude } \\
\hline & $100 \mathrm{~m}$ & $400 \mathrm{~m}$ & $1000 \mathrm{~m}$ \\
\hline & \multicolumn{3}{|c|}{ Soil organic matter } \\
\hline C $\left(\mathrm{Mg} \cdot \mathrm{ha}^{-1}\right)$ & 187 & 234 & 281 \\
\hline N $\left(\mathrm{Mg} \cdot \mathrm{ha}^{-1}\right)$ & 13.5 & 17.9 & 20.1 \\
\hline \multirow[t]{2}{*}{$\mathrm{P}\left(\mathrm{kg} \cdot \mathrm{ha}^{-1}\right)$} & 35 & 18 & 33 \\
\hline & \multicolumn{3}{|c|}{ Fine roots } \\
\hline C $\left(\mathrm{Mg} \cdot \mathrm{ha}^{-1}\right)$ & 1.94 & 1.82 & 5.52 \\
\hline \multirow[t]{2}{*}{$\mathrm{N}\left(\mathrm{Mg} \mathrm{ha}^{-1}\right)$} & 0.08 & 0.07 & 0.21 \\
\hline & \multicolumn{3}{|c|}{ Coarse roots } \\
\hline C $\left(\mathrm{Mg} \cdot \mathrm{ha}^{-1}\right)$ & 17.44 & 20.68 & 22.76 \\
\hline \multirow[t]{2}{*}{$\mathrm{N}\left(\mathrm{Mg} \cdot \mathrm{ha}^{-1}\right)$} & 0.17 & 0.17 & 0.19 \\
\hline & \multicolumn{3}{|c|}{ Total below ground } \\
\hline C $\left(\mathrm{Mg} \cdot \mathrm{ha}^{-1}\right)$ & 206 & 257 & 309 \\
\hline $\mathrm{N}\left(\mathrm{Mg} \cdot \mathrm{ha}^{-1}\right)$ & 13.8 & 18.1 & 20.5 \\
\hline
\end{tabular}

to $280 \mathrm{Mg} \mathrm{ha}^{-1}$ along the altitudinal range (Table 1 ). This increase in carbon soil stock was followed by an increase in the nitrogen stock, but was not followed by an increase in phosphorus stock. From $100 \mathrm{~m}$ asl to $1000 \mathrm{~m}$ asl there was a $7 \mathrm{Mg} \mathrm{ha}^{-1}$ increase in the nitrogen stock (Table 1). The same high concentration of carbon and nitrogen was also found for soils of the Serra da Mantiqueira located at higher altitudes (Dias et al., 2003; Benites et al., 2005; Simas et al., 2005).

The carbon stock in fine roots also increased with altitude (Sousa Neto et al., 2011), from $1.94 \mathrm{Mg} \mathrm{ha}^{-1}$ at $100 \mathrm{~m}$ asl to $5.52 \mathrm{Mg} \mathrm{ha}^{-1}$ at $1000 \mathrm{~m}$ asl (Table 1). The nitrogen stock in fine roots also increased in the same proportion observed for carbon (Table 1). Coarse roots also increased with altitude (Vieira et al., 2011), but not in the same proportion as observed for fine roots (Table 1).

As a consequence of the increase in carbon and nitrogen stocks in soil organic matter and roots, the total above ground carbon and nitrogen stocks increased approximately $50 \%$ along the altitudinal range, respectively (Table 1).

\subsection{Above-ground stocks}

Above-ground live biomass (AGLB) was also estimated along the same altitudinal range in Ubatuba (Alves et al., 2010). AGLB increased along the altitudinal range from approximately 210 to $280 \mathrm{Mg} \mathrm{ha}^{-1}$ (Table 2). Accordingly, carbon and nitrogen stocks in AGLB also increased with altitude (Table 2).

In addition to AGLB, there were also other components of the above ground stocks. These are snags, coarse

Table 2. Biomass, carbon and nitrogen stocks in different aboveground compartments in a Coastal Atlantic Forest, Ubatuba, São Paulo, Brazil.

\begin{tabular}{|c|c|c|c|}
\hline & \multicolumn{3}{|c|}{ Altitude } \\
\hline & $100 \mathrm{~m}$ & $400 \mathrm{~m}$ & $1000 \mathrm{~m}$ \\
\hline & \multicolumn{3}{|c|}{ Above ground live biomass } \\
\hline Biomass $\left(\mathrm{Mg} \cdot \mathrm{ha}^{-1}\right)$ & 209 & 254 & 283 \\
\hline $\mathrm{C}\left(\mathrm{Mg} \cdot \mathrm{ha}^{-1}\right)$ & 94 & 113 & 127 \\
\hline \multirow[t]{2}{*}{$\mathrm{N}\left(\mathrm{Mg}^{\mathrm{h}} \mathrm{ha}^{-1}\right)$} & 0.75 & 1.41 & 1.64 \\
\hline & \multicolumn{3}{|c|}{ Snags } \\
\hline Biomass (Mg.ha' $\left.{ }^{-1}\right)$ & 1.49 & 2.52 & 5.01 \\
\hline $\mathrm{C}\left(\mathrm{Mg}_{\mathrm{h}} \mathrm{ha}^{-1}\right)$ & 0.67 & 1.52 & 2.28 \\
\hline \multirow[t]{2}{*}{$\mathrm{N}\left(\mathrm{Mg} \cdot \mathrm{ha}^{-1}\right)$} & 0 & 0.02 & 0.01 \\
\hline & \multicolumn{3}{|c|}{ Coarse wood debris } \\
\hline Biomass $\left(\right.$ Mg.ha $\left.^{-1}\right)$ & 40 & 43 & 84 \\
\hline $\mathrm{C}\left(\mathrm{Mg} \cdot \mathrm{ha}^{-1}\right)$ & 9.95 & 9.33 & 16.85 \\
\hline \multirow[t]{2}{*}{$\mathrm{N}\left(\mathrm{Mg}_{\mathrm{h}} \mathrm{ha}^{-1}\right)$} & 0.06 & 0.20 & 0.12 \\
\hline & \multicolumn{3}{|c|}{ Litter } \\
\hline Biomass $\left(\right.$ Mg.ha $\left.^{-1}\right)$ & 8.40 & 7.70 & 5.50 \\
\hline $\mathrm{C}\left(\mathrm{Mg} \cdot \mathrm{ha}^{-1}\right)$ & 4.00 & 3.54 & 2.64 \\
\hline \multirow[t]{2}{*}{$\mathrm{N}\left(\mathrm{Mg}_{\mathrm{H}} \mathrm{ha}^{-1}\right)$} & 0.17 & 0.12 & 0.09 \\
\hline & \multicolumn{3}{|c|}{ Total above ground } \\
\hline Biomass $\left({\left.\mathrm{Mg} \cdot \mathrm{ha}^{-1}\right)}\right.$ & 259 & 307 & 378 \\
\hline C $\left(\mathrm{Mg} \cdot \mathrm{ha}^{-1}\right)$ & 109 & 127 & 149 \\
\hline $\mathrm{N}\left(\mathrm{Mg} \cdot \mathrm{ha}^{-1}\right)$ & 0.98 & 1.75 & 1.86 \\
\hline
\end{tabular}


wood debris and litter. All of these compartments had lower biomass than AGLB, only coarse wood debris was large enough to be comparable with AGLB (Table 2). Snags and coarse wood debris biomass and carbon and nitrogen stocks also increased with altitude. The increase of coarse wood debris was particularly large with the rise in altitude. At $100 \mathrm{~m}$ asl and $400 \mathrm{~m}$ asl the coarse wood debris was near $40 \mathrm{Mg} \mathrm{ha}^{-1}$, increasing to approximately $80 \mathrm{Mg} \mathrm{ha}^{-1}$ at $1000 \mathrm{~m}$ asl (Table 2). As the carbon and nitrogen content of the coarse wood debris depend on the stage of decomposition (Vieira et al., 2011) the carbon and, especially, the nitrogen stocks did not increase so vigorously with altitude. In fact, there was a decrease in the nitrogen stock with altitude for coarse wood debris (Table 2). The litterfall also decreased with altitude, from 8.40 to $5.50 \mathrm{Mg} \mathrm{ha}^{-1}$ (Sousa Neto et al., 2011). Accordingly, the carbon and nitrogen stocks in this zone also decreased with altitude (Table 2).

As the main component of the total above ground biomass is AGLB, there was a tendency of the total above ground carbon and nitrogen stocks to increase with altitude. There was practically an increase of almost $50 \mathrm{Mg} \mathrm{ha}^{-1}$ of carbon, and almost $1 \mathrm{Mg} \mathrm{ha}^{-1}$ of nitrogen, respectively, from 100 to $1000 \mathrm{~m}$ asl (Table 2).

\section{Carbon and Nitrogen Fluxes}

As an overarching process, we chose to work with the concept of net biome productivity (NBP) defined by Schulze et al. (2000) and slightly modified by Randerson et al. (2002) according to the Equation 1:

$$
\begin{aligned}
& \mathrm{NBP}=\mathrm{GPP}-\mathrm{R}_{\text {auto }}-\mathrm{R}_{\text {hetero }}-\mathrm{L}_{\text {fire }}- \\
& \mathrm{L}_{\text {leaching }}-\mathrm{L}_{\text {erosion }}-\mathrm{L}_{\text {hydrocarbon }}-\mathrm{L}_{\text {herbivory }} \pm \mathrm{L}_{\text {lateral }}
\end{aligned}
$$

where: GPP is the gross primary productivity; $\mathrm{R}_{\text {auto }}$ and $\mathrm{R}_{\text {hetero }}$ are carbon loss by autotrophy and heterotrophy respiration, respectively.

$\mathrm{L}_{\text {fire, }}, \mathrm{L}_{\text {leaching }}, \mathrm{L}_{\text {erosion }}, \mathrm{L}_{\mathrm{VOC}}, \mathrm{L}_{\text {herbivory }}, \mathrm{L}_{\text {lateral }}$ are the carbon losses to the atmosphere by forest fires, deep leaching, soil erosion, volatile organic carbon emissions, herbivory by animals respectively, and $\mathrm{L}_{\text {lateral }}$ is the loss or gain due to lateral exchange with other biomes, such as DOC, POC, and DIC export or import through rivers.

If gains of carbon are higher than carbon losses, NBP will be positive and carbon stocks in the biome increase; on the contrary, a negative NBP denotes that the carbon losses are higher than the gains, and carbon stocks in the biome decrease.

The Equation 1 is a broad conceptual framework to address the net primary productivity of an entire biome. Although this is a useful framework indicating the type of measurements needed for such a broad balance, reality is quite different and generally we conduct investigations on a small scale, typically on 1 ha plots. In these small plots net primary productivity (NPP) is defined as Equation 2:

$\mathrm{NPP}=\mathrm{GPP}-\mathrm{R}_{\text {auto }}-\mathrm{R}_{\text {hetero }}$
As NPP is also defined as any of the carbon incorporated into an ecosystem by plants in a specified time interval, NPP can be measured by the Equations 3, 4 and 5 (Girardin et al., 2010):

$$
\begin{aligned}
& \mathrm{NPP}=\mathrm{NPP}_{\mathrm{AG}}+\mathrm{NPP}_{\mathrm{BG}} \\
& \mathrm{NPP}_{\mathrm{AG}}=\mathrm{NPP}_{\text {stem }}+\mathrm{NPP}_{\text {canopy }}+\mathrm{NPP}_{\text {branch }}+\mathrm{NPP}_{\mathrm{VOC}} \\
& \mathrm{NPP}_{\mathrm{BG}}=\mathrm{NPP}_{\text {fineroot }}+\mathrm{NPP}_{\text {coarseroot }}+\mathrm{NPP}_{\text {exudates }}
\end{aligned}
$$

where: $\mathrm{NPP}_{\mathrm{AG}}$ and $\mathrm{NPP}_{\mathrm{BG}}$ represent the net primary productivity above and below ground, respectively; $\mathrm{NPP}_{\text {stem }}$, $\mathrm{NPP}_{\text {canopy }}, \mathrm{NPP}_{\text {branch }}$, and $\mathrm{NPP}_{\mathrm{vOC}}$ represent the net primary productivity of stems, canopy, branches and volatile organic carbon, respectively; $\mathrm{NPP}_{\text {fineroot }}, \mathrm{NPP}_{\text {coarseroot }}$, and NPP represent the net primary productivity of fine and coarse roots and roots exudates, respectively.

Most of the terms of Equations 2, 3 and 4 are not available for the Atlantic Forest. In the case of the NPP stem $_{\text {, which is }}$ the most important term of Equation 4 as was described above, we have the carbon biomass in the vegetation, but it is not yet known how this carbon stock varies with time.

Exceptions are losses attributed to autotrophy and heterotrophy respiration that indirectly are estimated by soil $\mathrm{CO}_{2}$ emissions (Davidson and Janssens, 2006), the $\mathrm{NPP}_{\text {canopy }}$ that is estimated through litterfall (Girardin et al., 2010), and the lateral exchange of carbon via river discharge $\left(\mathrm{L}_{\text {lateral }}\right)$. These last two terms were measured in the Ubatuba altitudinal range, and canopy litterfall was measured in Ubatuba and also in other areas.

The soil $\mathrm{CO}_{2}$ emissions in the coastal Atlantic Forest of Ubatuba did not vary with altitude and was equal to approximately $3.6 \mathrm{Mg} \mathrm{C} \mathrm{ha}^{-1}$ year $^{-1}$ (Sousa Neto et al., 2011). On the other hand, the litterfall ( NPP $_{\text {canopy }}$ ) decreased with altitude (Sousa Neto et al., 2011). At $100 \mathrm{~m}$ the litterfall was equal to $4.0 \mathrm{Mg} \mathrm{C} \mathrm{ha}^{-1} \mathrm{year}^{-1}$, decreasing to $3.4 \mathrm{Mg} \mathrm{C} \mathrm{ha}^{-1}$ year $^{-1}$ at $400 \mathrm{~m}$ and further to 2.6 Mg C ha-1 year $^{-1}$ at $1000 \mathrm{~m}$ (Sousa Neto et al., 2011).

The export of carbon (dissolved organic + dissolved inorganic carbon) from rivers and streams was estimated also in the Atlantic Forest of Ubatuba, and it was estimated to be approximately $0.1 \mathrm{Mg} \mathrm{C} \mathrm{ha}^{-1}$ year $^{-1}$ (Andrade et al., 2010).

According to Girardin et al. (2010) either in Amazon lowland tropical forests as well as in Amazon montane tropical forests, the main components of the NPP are the $\mathrm{NPP}_{\text {canopy }}, \mathrm{NPP}_{\text {stem }}$, and $\mathrm{NPP}_{\text {fineroots }}$. So far we only have the NPP ${ }_{\text {canopy }}$ available for the Atlantic Forest, which was indirectly estimated through litterfall. In montane Amazon Forests (1000 to $2000 \mathrm{~m}$ asl) this component varied from approximately 1.5 to $3.0 \mathrm{Mg} \mathrm{C}^{-1}$ year $^{-1}$. In Amazon lowland forests with altitudes between 0 to $200 \mathrm{~m}$ asl, the NPP was higher than for the Amazon montane forests and varied from 3.0 to almost 7.0 $\mathrm{Mg} \mathrm{C}^{-1}$ year $^{-1}$. In the Ubatuba elevation range, at the montane forests (1000 $\mathrm{m}$ asl), the $\mathrm{NPP}_{\text {canopy }}$ was equal to $2.6 \mathrm{Mg} \mathrm{C} \mathrm{ha}^{-1}$ year $^{-1}$, which is in the range observed in montane Amazon Forests. The NPP at lowland forests $(100 \mathrm{~m}$ asl $)$ of Ubatuba was equal to 
4.0 $\mathrm{Mg} \mathrm{C} \mathrm{ha}^{-1}$ year $^{-1}$, which is similar to the lowest values observed in lowland Amazon forests. It is interesting to note that the output carbon flux via respiration, estimated by $\mathrm{CO}_{2}$ emissions to the atmosphere, in the Ubatuba elevation range was approximately $3.5 \mathrm{Mg} \mathrm{C} \mathrm{ha}^{-1}$ year $^{-1}$, which is similar to the NPP ${ }_{\text {canopy }}$ observed in Ubatuba. On the other hand, the carbon output via stream fluxes was very low $\left(0.1 \mathrm{Mg} \mathrm{C} \mathrm{ha-1}^{-1}\right.$ year $\left.^{-1}\right)$ compared with the NPP $\mathrm{Canopy}_{\text {and }}$ with $\mathrm{CO}_{2}$ emissions.

The nitrogen mass balance is slightly different than for carbon, and it is described in the Equation 6:

$\Delta \mathrm{N}_{\text {biome }}=\mathrm{F}_{\mathrm{BNF}}+\mathrm{F}_{\text {atm-d }}-\mathrm{F}_{\text {atm-e }} \pm \mathrm{F}_{\text {veg }} \pm \mathrm{F}_{\text {soil }} \pm \mathrm{F}_{\text {lateral }}$

where: $\Delta \mathrm{N}_{\text {biome }}$ is the nitrogen variation in the biome during a period of time; $\mathrm{F}_{\mathrm{BNF}}$ is the nitrogen input due to the natural biological nitrogen fixation; $\mathrm{F}_{\mathrm{atm}-\mathrm{d}}$ is the nitrogen input due to nitrogen dry and wet deposition; $\mathrm{F}_{\text {atm-e }}$ is the nitrogen loss due to volatilisation and denitrification; $\mathrm{F}_{\mathrm{veg}}$ is the increase or decrease of nitrogen stock in the biomass considering a period of time; $\mathrm{F}_{\text {soil }}$ is the increase or decrease of nitrogen stock in the soil considering a period of time; $\mathrm{F}_{\text {lateral }}$ is the gain or loss of nitrogen due to any lateral exchange of nitrogen with another biome.

As for carbon, most terms of Equation 6 are not yet available for the coastal Atlantic Forest. We hope to have $\mathrm{F}_{\text {veg }}$ and $\mathrm{F}_{\text {soil }}$ estimated in 2013 as explained above for carbon. $\mathrm{F}_{\mathrm{BNF}}$ are not only missing for the Atlantic Forest but for almost all tropical forests. The only values that we have available were derived by Cleveland et al. (1999) based on very few field measurements. According to these estimates Atlantic Forest should fix approximately 20 to $25 \mathrm{~kg} \mathrm{~N} \mathrm{ha}^{-1}$ year $^{-1}$.

Atmospheric $\mathrm{N}$ deposition $\left(\mathrm{F}_{\text {atm-d }}\right)$ is available for some areas of the Atlantic Forest that are still less disturbed. In the Parque Estadual de Intervales, located in the southern region of the State of São Paulo, Almeida (2006) found a wet nitrogen deposition for two consecutive years varying from 3.1 to $3.8 \mathrm{~kg} \mathrm{~N} \mathrm{ha}^{-1}$ year $^{-1}$. A similar $\mathrm{N}$ wet deposition was found in the Ilha Grande, an inland located on the coast of the State of Rio de Janeiro (Souza et al., 2006). The highest deposition in less disturbed areas was found by Mello and Almeida (2004) in the Parque Nacional de Itatiaia located on the border between the states of São Paulo and Rio de Janeiro. At the highest altitude of the park $(2600 \mathrm{~m}$ asl) the $\mathrm{N}$ wet deposition was similar to other areas $\left(3.3 \mathrm{~kg} \mathrm{~N}^{-1}\right.$ year $\left.^{-1}\right)$, but at $820 \mathrm{~m}$ asl, the $\mathrm{N}$ wet deposition increased to approximately $5.4 \mathrm{~kg} \mathrm{~N} \mathrm{ha}^{-1}$ year $^{-1}$. The lowest $\mathrm{N}$ wet deposition was found in the Parque Estadual da Serra do Mar at Santa Virgínia at an altitude of approximately $1000 \mathrm{~m}$. This area is located in the northern coastal region of the State of São Paulo, near the city of Ubatuba. In two consecutive years, the $\mathrm{N}$ wet deposition varied from 1.0 to $1.1 \mathrm{~kg} \mathrm{~N} \mathrm{ha}^{-1}$ year $^{-1}$ (Groppo, 2010).

In disturbed areas such as the city of São Paulo, the N wet deposition increased up to almost $26 \mathrm{~kg} \mathrm{~N} \mathrm{ha}^{-1}$ year $^{-1}$ (Forti et al., 2007), and at the Serra do Orgãos near the city of the Rio de Janeiro the deposition was approximately $12 \mathrm{~kg} \mathrm{~N} \mathrm{ha}^{-1}$ year $^{-1}$ (Rodrigues et al., 2007). Additionally,
Forti et al. (2007) also found high $\mathrm{N}$ wet deposition values in the Serra do Mar near the city of Cunha, a region apparently less disturbed. These authors found a deposition of almost $10 \mathrm{~kg} \mathrm{~N} \mathrm{ha}^{-1}$ year $^{-1}$. This is approximately 10 times higher than the deposition found in Santa Virgínia, which is only approximately $50 \mathrm{~km}$ apart.

The loss of $\mathrm{N}$ by gas emission $\left(\mathrm{F}_{\text {atm-e }}\right)$ includes losses by volatilisation $\left(\mathrm{NH}_{3}\right)$ and losses by denitrification $\left(\mathrm{N}_{2}\right.$ and $\mathrm{N}_{2} \mathrm{O}$ ). We have loss of nitrogen via $\mathrm{N}_{2} \mathrm{O}$ available for the Atlantic Forest. Such losses were estimated in the elevation range of the Ubatuba Atlantic Forest (Sousa Neto et al., 2011), and in the Tiguá Biological Reserve in the State of Rio de Janeiro (Maddock et al., 2001). In the elevation range of Ubatuba, the $\mathrm{N}_{2} \mathrm{O}$ flux decreased with altitude. At $100 \mathrm{~m}$ asl, the flux was equal to $3.4 \mathrm{~kg} \mathrm{~N} \mathrm{ha}^{-1} \mathrm{year}^{-1}$, and a decrease to $1.3 \mathrm{~kg} \mathrm{~N} \mathrm{ha}^{-1}$ year $^{-1}$ and $0.9 \mathrm{~kg} \mathrm{~N} \mathrm{ha}^{-1}$ year $^{-1}$ at $400 \mathrm{~m}$ and $1000 \mathrm{~m}$ asl, respectively (Sousa Neto et al., 2011). The emissions found by Maddock et al. (2001) was equal to $4.7 \mathrm{~kg} \mathrm{~N} \mathrm{ha}^{-1}$ year $^{-1}$, which is similar to the one found at $1000 \mathrm{~m}$ asl in the Ubatuba elevation range.

The nitrogen export via river and streams $\left(\mathrm{F}_{\text {lateral }}\right)$ varied widely along the altitudinal range of Ubatuba. At low altitudes (0 to $100 \mathrm{~m}$ asl), the dissolved inorganic flux of nitrogen was approximately $11 \mathrm{~kg} \mathrm{~N} \mathrm{ha}^{-1}$ year $^{-1}$ (Andrade et al., 2010), decreasing abruptly to less than $1 \mathrm{~kg} \mathrm{~N} \mathrm{ha}^{-1}$ year $^{-1}$ at $1000 \mathrm{~m}$ asl (Groppo, 2010). In the Parque Estadual da Serra do Mar near the city of Cunha, $50 \mathrm{~km}$ apart from the Ubatuba altitudinal range, Forti et al. (2007) found a flux of $2.7 \mathrm{~kg} \mathrm{~N} \mathrm{ha}^{-1}$ year ${ }^{-1}$ at an altitude of approximately $1,000 \mathrm{~m}$ asl. Although this last value is indeed higher than the one found at the same altitude in the Ubatuba elevation range, it is also significantly lower than the flux found in the lowlands of the Ubatuba elevation range.

Comparing the different nitrogen fluxes, it is clear that the highest input flux in the biological nitrogen fixation $\left(20 \mathrm{~kg} \mathrm{~N} \mathrm{ha}^{-1}\right.$ year $\left.^{-1}\right)$ and the highest output flux is via streams, especially at low altitudes, where the dissolved nitrogen inorganic flux were approximately half of the biological nitrogen fixation input. In less disturbed areas the input via wet deposition varies from 1.0 to $5.0 \mathrm{~kg} \mathrm{~N} \mathrm{ha}^{-1}$ year $^{-1}$, and in more disturbed places, could vary from 10 to $26 \mathrm{~kg} \mathrm{~N} \mathrm{ha}^{-1}$ year $^{-1}$, which is similar to the input via biological nitrogen fixation. Finally, the $\mathrm{N}$ output via $\mathrm{N}_{2} \mathrm{O}$ emissions to the atmosphere is similar to the input via wet deposition, varying from 1.0 to $4.7 \mathrm{~kg} \mathrm{~N} \mathrm{ha}^{-1} \mathrm{year}^{-1}$.

\section{Potential Impacts of Climate Change on the Carbon and Nitrogen Cycles of the Coastal Atlantic Forest of the Southeast Region of Brazil}

We still have limited knowledge on the functioning of the Atlantic Forest. Most of the information available focuses on coastal forests of southeastern of Brazil. As a consequence we have a limited capability to forecast potential impacts of climate changes on the carbon and nitrogen cycles of this biome. Therefore, conclusions on 
this topic should be made with caution due the lack of available data. On the other hand, reviewing the topic is a useful exercise because it will designate areas of data that are most urgently needed.

Using regional climate models, Marengo et al. (2009, 2010) made projections for a IPCC A2 high emission scenario for 2071-2100 for South America and sub-regions of Brazil. As most of our data on carbon and nitrogen cycles of the Atlantic Forest focus on the southeast region of Brazil, we focused on the effects climate changes on this region to address potential changes in the functioning of the Atlantic Forest. One of the consequences of the above fact is that data on the functioning of the Atlantic Forest spanning other longitudes, and most importantly, over other latitudes are urgently needed.

The most ubiquitous climate change projected by three regional climate models used by Marengo et al. (2010) was an increase of temperature throughout the country at the end of this century. Changes in precipitation projected for the end of this century are less robust than for temperature, with a higher degree of variability among the regional climate models (Marengo et al., 2010). Having this uncertainty in mind, the main projected changes are an increase in the annual temperature over the southeastern region of Brazil, coupled with a decrease in rainfall during the austral winter months (June - August), followed by an increase in extreme events of precipitation during the austral summer months (December - February) (Marengo et al., 2009).

One of the most notorious features of tropical forests is their ability to hold high carbon and nitrogen stocks, either below as well above ground (Trumbore et al., 1995). Meier and Leuschner (2010) argue that increases in temperature may transform forest ecosystems into carbon sources. This would occur because potential increases in forest productivity due to the increases in temperature and atmospheric $\mathrm{CO}_{2}$ may not compensate for $\mathrm{CO}_{2}$ soil emissions from faster decomposition of labile carbon caused by higher temperatures.

It is well known that decomposition rates and soil respiration increase with the increase of soil and air temperatures (Kirschbaum, 2000; Raich et al., 2006; Wagai et al., 2008). In turn, increases in decomposition rates and soil respiration may enhance soil carbon losses (Biasi et al., 2008; Dorrepaal et al., 2009). However, if rainfall decreases during the austral winter months, it may equilibrate decomposition rates during this period. Despite the increase in extreme events of precipitation during the austral summer months, a period of higher decomposition in tropical forests (Villela and Proctor, 2002; Villela et al., 2006), may intensify organic matter decomposition, probably improving soil carbon and nitrogen losses as a whole, caused by the litter and soil organic matter decomposition and mineralization rate.

Three pieces of evidence from the Ubatuba altitudinal range suggest that carbon and nitrogen dynamics are closely related to temperature in these forests. Sousa Neto et al. (2011) found a consistent decrease in soil temperature with rising elevation. At 400 and 1,000 $\mathrm{m}$ asl, there was a significant direct correlation between soil $\mathrm{CO}_{2}$ emission and soil temperature. This relation was further confirmed by a field experiment where soils at $1,000 \mathrm{~m}$ asl were warmed artificially and a significant increase in $\mathrm{CO}_{2}$ emissions was observed in warmer soils (Luiz Felipe Martins, master thesis, data not published). The emissions of $\mathrm{N}_{2} \mathrm{O}$ decreased with altitude in the Ubatuba elevation gradient (Sousa Neto et al., 2011); and at same time, an increase in the $\mathrm{N}_{2} \mathrm{O}$ emission was observed in warmed soils (Luiz Felipe Martins, master thesis, data not published). Finally, Vieira et al. (2011) found a strong correlation with carbon and nitrogen above and below ground and soil temperature in the Ubatuba gradient. Using a regression curve between stocks and temperature, they speculated that an increase of $1{ }^{\circ} \mathrm{C}$ in mean soil temperature could result in an eventual net transfer from the forest to the atmosphere of approximately $17 \mathrm{Mg} \mathrm{C} \mathrm{ha}^{-1}$ and $1.0 \mathrm{Mg} \mathrm{N} \mathrm{ha}^{-1}$. Lowland net primary productivity in the Amazon terra-firme forests varies from approximately 10 to $16 \mathrm{Mg} \mathrm{C} \mathrm{ha}^{-1}$ (Aragão et al., 2009); and montane net primary productivity in the Amazon region varied from 6.0 to $6.5 \mathrm{Mg} \mathrm{C} \mathrm{ha}^{-1}$ (Girardin et al., 2010). This kind of comparison indicates the magnitude of carbon emissions that can be caused by global warming in tropical forests.

This decrease of carbon stocks with an increase of temperature found in the coastal Atlantic Forest of Ubatuba is similar to several studies that have found the same trend (Jobbagy and Jackson, 2000; Amundson, 2003). The three pieces of evidence considered in this study lead us to conclude that climate warming may reduce the amount of carbon and nitrogen stored in the coastal Atlantic Forest, turning these ecosystems into carbon and nitrogen sources.

It is clear that these are preliminary conclusions about a complex issue, since decomposition rates are not only driven by temperature (Davidson and Janssen, 2006), but the patterns reported here are unequivocal, and should support future studies relating climatic conditions to biogeochemical functioning of the Atlantic Forest, especially in areas not addressed in this study.

Acknowledgements - We thank the Executive Secretary of Painel Brasileiro de Mudanças Climáticas (PBMC), Sciences and Technology Ministry - MCT/MMA-, for the invitation to participate on the working group 1 (GT1) - Scientific Base of Climatic Changes, and the Coordinators of the workshop "Brazilian Biomes and Climatic Changes: An Ecosystem Ecology Approach", of INCT - Climatic Changes, Component: Biogeochemical Cycles, for supervising. The authors also thank the National Research Council of Brazil (CNPq), FAPERJ Fundação Carlos Chagas Filho de Amparo à Pesquisa do Estado do Rio de Janeiro, and FAPESP - Fundação de Amparo à Pesquisa do Estado de São Paulo (Thematic Project Functional Gradient - Process Number 03/12595-7) for financial support of related projects. We also thank the researchers, students and technicians involved on those projects.

\section{References}

ALMEIDA, VPS., 2006. Acidez orgânica na precipitação e uso do solo no Estado de São Paulo: variabilidade espacial e temporal. Piracicaba: Centro de Energia Nuclear na Agricultura, 
Universidade de São Paulo. 97 p. Tese de Doutorado em Química na Agricultura e no Ambiente.

ALVES, LF., VIEIRA, SA., SCARANELLO, MA., CAMARGO, PB., SANTOS, FA.M., JOLY, CA. and MARTINELLY, LA., 2010. Forest structure and live aboveground biomass variation along an elevational gradient of tropical Atlantic moist forest (Brazil). Forest Ecology and Management, vol. 260, no. 5, p. 679-691. http://dx.doi.org/10.1016/j.foreco.2010.05.023

AMUNDSON, R., 2003. Global patterns of the isotopic composition of soil and plant nitrogen. Global Biogeochemical Cycles, vol. 17, no. 1, p. 1031-1042. http://dx.doi.org/10.1029/2002GB001903

ANDRADE, TMB., CAMARGO, PB., SILVA, DML., PICCOLO, MC., VIEIRA, SA., ALVES, LF., JOLY, CA. and MARTINELLI, LA., 2010. Dynamics of dissolved forms of carbon and inorganic nitrogen in small watersheds of the Coastal Atlantic Forest in Southeast Brazil. Water Air Soil Pollution, vol. 214, no. 1-4, p. 393-408.

ARAGÃO, LEOC., MALHI, Y., METCALFE, DB., SILVAESPEJO, JE., JIMÉNEZ, E., NAVARRETE, D., ALMEIDA, S., COSTA, ACL., SALINAS, N., PHILLIPS, OL., ANDERSON, LO., BAKER, TR., GONÇALVES, PH., HUAMÁN-OVALLE, J., MAMANI-SOLÓRZANO, M., MEIR, P., MONTEAGUDO, A., PENUELA, MC., PRIETO, A., QUESADA, CA., ROZASDÁVILLA, A., RUDAS, A., SILVA JUNIOR, JA. and VÁSQUEZ, R., 2009. Above- and below-ground net primary productivity across ten Amazonian forests on contrasting soils. Biogeosciences, vol. 6 , no. 12 , p. $2759-2778$.

BENITES, VM., MENDONÇA, ES., SCHAEFER, CEGR., NOVOTNY, EH., REIS, EL., KER, JC., 2005. Properties of black soil humic acids from high altitude rocky complexes in Brazil. Geoderma, vol. 127, p. 104-113. http://dx.doi.org/10.1016/j. geoderma.2004.11.020

BIASI, C., MEYER, H., RUSALIMOVA, O., HÄMMERLE, R., KAISER, C., BARANYI, C., DAIMS, H., LASHCHISNKY, N., BARSUKOV, P. and RICHTER, A., 2008. Initial effects of experimental warming on carbon exchange rates, plant growth and microbial dynamics of a lichen-rich dwarf shrub tundra in Siberia. Plant and Soil, vol. 307, no. 1-2, p. 191-205. http://dx.doi. org/10.1007/s11104-008-9596-2

BLANKINSHIP, JC., NIKLAUS, PA, and HUNGATE, BA., 2011. A meta-analysis of responses of soil biota to global change. Oecologia, vol. 165 , no. 3, p. 553-565.

BRANDO, PM., NEPSTAD, DC., DAVIDSON, EA., TRUMBORE, SE., RAY, D. and CAMARGO, P., 2008. Drought effects on litterfall, wood production and belowground carbon cycling in an Amazon forest: results of a throughfall reduction experiment. Philosophical Transactions of the Royal Society B Biological Sciences, vol. 363, no. 1498, p. 1839-1848.

BROOK, BW., SODHI, NS. and NG, PKL., 2003. Catastrophic extinctions follow deforestation in Singapore. Nature, vol. 424, no. 6947 , p. $420-426$.

BUNKER, DE., DECLERCK, F., BRADFORD, JC., COLWELL, RK., PERFECTO, I., PHILLIPS, OL., SANKARAN, M. and NAEEM, S., 2005. Species loss and aboveground carbon storage in a tropical forest. Science, vol. 310, p. 1029-1031.

CALVI, GP., PEREIRA, MG., ESPÍNDULA JÚNIOR,A. 2009. Litter production and nutrient addition in Atlantic Forest áreas in Santa Maria de Jetibá, ES. Ciência Florestal, vol. 19, no. 2, p. 131-138.

CARDOSO DA SILVA, JM., CARDOSO DE SOUSA, M. and CASTELLETTI, CHM., 2004. Areas of endemism for passerine birds in the Atlantic forest, South America. Global
Ecology and Biogeography, vol. 13, no. 1, p. 85-92. http://dx.doi. org/10.1111/j.1466-882X.2004.00077.x

CHAPIN III, FS., ZAVALETA, ES., EVINER, VT., NAYLOR, RL., VITOUSEK, PM., REYNOLDS, HL., HOOPER, DU., LAVOREL, S., SALA, OE., HOBBIE, SE., MACK, MC. and DIAZ, S., 2000. Consequences of changing biodiversity. Nature, vol. 405 , p. $234-242$.

CLEVELAND, CC., TOWNSEND, AR., SCHIMEL, DS., FISHER, H., HOWARTH, RW., HEDIN, LO., PERAKIS, SS., LATTY, EF., VON FISCHER, JC., ELSEROAD, A. and WASSON, MF., 1999. Global patterns of terrestrial biological nitrogen (N2) fixation in natural ecosystems. Global Biogeochemical Cycles, vol. 13, p. 623-645. http://dx.doi.org/10.1029/1999GB900014

DANGLES, O. and MALMQVIST, B., 2004. Species richnessdecomposition relationships depend on species dominance. Ecology Letters, vol. 7, p. 395-402. http://dx.doi.org/10.1111/j.14610248.2004.00591.x

DAVIDSON, EA., and JANSSENS, IA., 2006. Temperature sensitivity of soil carbon decomposition and feedbacks to climate change. Nature, vol. 440, no. 7081, p. 165-73.

DIAS, HCT., SCHAEFFER, CEGR., FERNANDES FILHO, EI., OLIVEIRA, AP., MICHEL, RFM. and LEMOS, JR., 2003. Caracterização de solos altimontanos em dois transectos no Parque Estadual do Ibitipoca (MG). Revista Brasileira de Ciência do Solo, vol. 27, p. 469-481.

DORREPAAL, E., TOET, S., VAN LOGTESTIJN, RSP., SWART, E., VAN DE WEG, MJ., CALLAGHAN, TV., and AERTS, R., 2009. Carbon respiration from subsurface peat accelerated by climate warming in the subarctic. Nature, vol. 460, no. 7255 , p. 616-619. http://dx.doi.org/10.1038/nature08216

FORTI, M., BOUROTTE, C., DECICCO, V., ARCOVA, F. and RANZINI, M., 2007. Fluxes of solute in two catchments with contrasting deposition loads in Atlantic Forest (Serra do Mar/ SP-Brazil). Applied Geochemistry, vol. 22, no. 6, p. 1149-1156. http://dx.doi.org/10.1016/j.apgeochem.2007.03.006

GIRARDIN, CAJ., MALHI, Y., ARAGÃO, LEOC., MAMANI, M., HUARACA HUASCO, W., DURAND, L., FEELEY, KJ., RAPP, J., SILVA-ESPEJO, JE., SILMAN, M., SALINAS, N. and WHITTAKER, RJ., 2010. Net primary productivity allocation and cycling of carbon along a tropical forest elevational transect in the Peruvian Andes. Global Change Biology, vol. 16, no. 12, p. 3176-3192. http://dx.doi.org/10.1111/j.1365-2486.2010.02235.x

GRIME, JP., 1998. Benefits of plant diversity to ecosystems: immediate, filter and founder effects. Journal of Ecology, vol. 86, p. 902-910. http://dx.doi.org/10.1046/j.1365-2745.1998.00306.x

GROPPO, JD., 2010. Caracterização hidrológica e dinâmica do nitrogênio em uma microbacia com cobertura florestal (Mata Atlântica), no Parque Estadual da Serra do Mar, núcleo Santa Virgínia. Piracicaba: Centro de Energia Nuclear na Agricultura, Universidade de São Paulo. 80 p. Tese de Doutorado em Química na Agricultura e no Ambiente.

HUBBELL, SP., 2001. The unified theory of biodiversity and biogeography. Princeton: Princeton University Press. 448 p.

JOBBAGY, EG. and JACKSON, RB., 2000. The vertical distribution of soil organic carbon and its relation to climate and vegetation. Ecological Applications, vol, 10, no. 2, p. 423-36. http://dx.doi. org/10.1890/1051-0761(2000)010[0423:TVDOSO]2.0.CO;2

KINZIG, AP., PACALA, S. and TILMAN, D., 2002. The functional consequences of biodiversity: empirical progress and theoretical extensions. Princeton: Princeton University Press. 368 p. 
KIRSCHBAUM, MUF., 2000. Will changes in soil organic carbon act as a positive or negative feedback on global warming? Biogeochemistry, vol. 27, p. 753-760.

KITAYAMA, K. and AIBA, S., 2002. Ecosystem structure and productivity of tropical rain forests along altitudinal gradients with contrasting soil phosphorus pools on Mount Kinabalu, Borneo. Journal of Ecology, vol. 90, p. 37-51. http://dx.doi. org/10.1046/j.0022-0477.2001.00634.x

LALIBERTÉ, E., WELLS, JA., DECLERCK, F., METCALFE, DJ., CATTERALL, CP., QUEIROZ, C., AUBIN, I., BONSER, SP., DING, Y., FRATERRIGO, JM., MCNAMARA, S., MORGAN, JW., MERLOS, DS., VESK, PA. and MAYFIELD, MM., 2010. Land-use intensification reduces functional redundancy and response diversity in plant communities. Ecology Letters, vol. 13, p. 76-86.

LARSEN, TH., WILLIAMS, NM. and KREMEN, C., 2005. Extinction order and altered community structure rapidly disrupt ecosystem functioning. Ecology Letters, vol. 8, p. 538-547. PMid:21352458. http://dx.doi.org/10.1111/j.1461-0248.2005.00749.x

LAURANCE, WF., 2009. Conserving the hottest of the hotspots. Biological Conservation, vol. 142, no. 6, p. 1137-1137. http:// dx.doi.org/10.1016/j.biocon.2008.10.011

LAURANCE, WF., NASCIMENTO, HEM., LAURANCE, SG., ANDRADE, AC., FEARNSIDE, PM., RIBEIRO, JEL. and CAPRETZ, RL., 2006. Rain forest fragmentation and the proliferation of successional trees. Ecology, vol. 87, p. 469-482. PMid:16637371. http://dx.doi.org/10.1890/05-0064

LAVOREL, S. and GARNIER, E., 2002. Predicting changes in community composition and ecosystem functioning from plant traits: revisiting the Holy Grail. Funct Ecology, vol. 16, p. 545556. http://dx.doi.org/10.1046/j.1365-2435.2002.00664.x

LÔBO, D., LEÃO, T., MELO, FPL., SANTOS, AMM. and TABARELLI, M., 2011. Forest fragmentation drives Atlantic forest of northeastern Brazil to biotic homogenization. Diversity and Distributions, vol. 17, no. 2, p. 287-296.

LODGE, DJ., MCDOWELL, WH., and MCSWINEY, CP., 1994. The importance of nutrient pulses in tropical forests. Trends in Ecology and Evolution, vol. 9, p. 384-387. http://dx.doi. org/10.1016/0169-5347(94)90060-4

LOISELLE, BA., GRAHAM, CH., GOERCK, JM., and RIBEIRO, MC., 2010. Assessing the impact of deforestation and climate change on the range size and environmental niche of bird species in the Atlantic forests, Brazil. Journal of Biogeography, vol. 37, no. 7, p. 1288-1301. http://dx.doi.org/10.1111/j.1365-2699.2010.02285.x

LOREAU, M., NAEEM, S. and INCHAUSTI, P., 2002. Biodiversity and ecosystem functioning: synthesis and perspectives. Oxford: Oxford University Press. 312 p.

LUIZÃO, FJ. and SCHUBART, HOR., 1987. Litter production and decomposition in a Terra-Firme forest of Central Amazonia. Experientia, vol. 43, p. 259-265.

MACÍA, MJ. and SVENNING, J-C., 2005. Oligarchic dominance in western Amazonian plant communities. Journal of Tropical Ecology, vol. 21, p. 613-626.

MADDOCK, JEL., DOS SANTOS, MB., PRATA, KR., 2001. Nitrous oxide emission from soil of the Mata Atlantica, Rio de Janeiro State, Brazil. Journal of Geophysical Research, vol. 106, p. 23055-23060. http://dx.doi.org/10.1029/2000JD000126

MARENGO, JA., AMBRIZZI, T., DA ROCHA, RP., ALVES, LM., CUADRA, SV., VALVERDE, MC., TORRES, RR., SANTOS, DC. and FERRAZ, SET., 2010. Future change of climate in South America in the late twenty-first century: intercomparison of scenarios from three regional climate models. Climate Dynamics, vol. 35, p. 1073-109. http://dx.doi.org/10.1007/s00382-009-0721-6
MARENGO, JA., JONES, R., ALVES, LM., and VALVERDE, MC., 2009. Future change of temperature and precipitation extremes in South America as derived from the PRECIS regional climate modeling system. International Journal of Climatology, vol. 29, p. 2241-2255. http://dx.doi.org/10.1002/joc. 1863

MAZUREC, AP. and VILLELA, DM., 1998. Produção e camada da serrapilheira em uma Mata Atlântica na Serra do Imbé, Norte Fluminense, em diferentes altitudes. In Anais do IV Simpósio de Ecossistemas Brasileiros, 1998. Águas de Lindóia: ACIESP. p. 36-42.

MEIER, IC. and LEUSCHNER, C., 2010. Variation of soil and biomass carbon pools in beech forests across a precipitation gradient. Global Change Biology, vol. 16, p. 1035-1045. http:// dx.doi.org/10.1111/j.1365-2486.2009.02074.x

MELLO, W. and ALMEIDA, M., 2004. Rainwater chemistry at the summit and southern flank of the Itatiaia massif, Southeastern Brazil. Environmental Pollution, vol. 129, no. 1, p. 63-68. PMid:14749070. http://dx.doi.org/10.1016/j.envpol.2003.09.026

MORAES, RM., DELITTI, WBC. and VUONO, YS., 1999. Litterfall and litter nutrient content in two Brazilian Tropical Forest. Revista Brasileira de Botânica, vol. 22, p. 9-16.

NAEEM, S., BUNKER, DE., HECTOR, A., LOREAU, M. and PERRINGS, C., 2009. Biodiversity, ecosystem functioning, and human wellbeing: An ecological and economic perspective. Oxford: Oxford University Press. 384 p.

NOVACEK, MJ. and CLELAND, EE., 2001. The current biodiversity extinction event: Scenarios for mitigation and recovery. Proceedings of the National Academy of Sciences of the United States of America, vol. 98, p. 5466-5470.

PIMENTEL, MCP., BARROS, MJ., CIRNE, P., DE MATTOS, EA., OLIVEIRA, RC., PEREIRA, MCA., SCARANO, FR., ZALUAR, HLT. and ARAUJO, DSD., 2007. Spatial variation in the structure and floristic composition of "restinga" vegetation in southeastern Brazil. Revista Brasileira de Botânica, vol. 30, p. 543-551.

PORTELA, RCQ. and SANTOS, FAM., 2007. Produção e espessura da serapilheira na borda e interior de fragmentos florestais de mata atlântica de diferentes tamanhos. Revista Brasileira de Botânica, vol. 30, p. 271-280.

QUESTED, H., ERIKSSON, O., FORTUNEL, C. and GARNIER, E., 2007. Plant traits relate to whole-community litter quality and decomposition following land use change. Functional Ecology, vol. 21, p. 1016-1026. http://dx.doi.org/10.1111/j.13652435.2007.01324.x

RAICH, JW., RUSSELL, AE., KITAYAMA, K., PARTON, WJ., VITOUSEK, PM., 2006. Temperature influences carbon accumulation in moist tropical forests. Ecology, vol. 87, p. 76-87. PMid:16634298. http://dx.doi.org/10.1890/05-0023

RANDERSON, JT., CHAPIN, FS., HARDEN, JW., NEFF, JC. and HARMON, ME., 2002. Net Ecosystem Production: a Comprehensive Measure of Net Carbon Accumulation by Ecosystems. Ecological Applications, vol. 12, no. 4, p. $937-$ 947. http://dx.doi.org/10.1890/1051-0761(2002)012[0937:NE PACM]2.0.CO;2

REED, SC., CLEVELAND, CC. and TOWNSEND, AR., 2008. Tree species control rates of free-living nitrogen fixation in a tropical rain forest. Ecology, vol. 89, p. 2924-2934.

RIBEIRO, MC., METZGER, JP., MARTENSEN, AC., PONZONI, FJ., and HIROTA, MM., 2009. The Brazilian Atlantic Forest: How much is left, and how is the remaining forest distributed? Implications for conservation. Biological Conservation, vol. 142, no. 6, p. 1141-1153. http://dx.doi.org/10.1016/j.biocon.2009.02.021 
RICHMOND, CE., BREITBURG, DL. and ROSE, KA., 2005. The role of environmental generalist species in ecosystem function. Ecological Modelling, vol. 188, p. 279-295. http:// dx.doi.org/10.1016/j.ecolmodel.2005.03.002

RODRIGUES, RAR., DE MELLO, WZ. AND DE SOUZA, PA., 2007. Aporte atmosférico de amônio, nitrato e sulfato em área de floresta ombrófila densa montana na Serra dos Órgãos, RJ. Quimica Nova, vol. 30, no. 8, p. 1842-1848.

RUIZ-JAEN, MC. and POTVIN, C., 2011. Can we predict carbon stocks in tropical ecosystems from tree diversity? Comparing species and functional diversity in a plantation and a natural forest. New Phytologist, vol. 189, p. 978-987. PMid:20958305. http://dx.doi.org/10.1111/j.1469-8137.2010.03501.x

SAITER, FZ., WENDT, T., VILLELA, DM. and NASCIMENTO, MT., 2009. Rain Forests: Floristics. In: INTERNATIONAL COMMISSION ON TROPICAL BIOLOGY AND NATURAL RESOURCES. Encyclopedia of Life Support Systems (EOLSS). Oxford: UNESCO, Eolss Publishers. p. 203-228. vol.1.

SALA, OE., CHAPIN, FS., ARMESTO, JJ., BERLOW, E., BLOOMFIELD, J., DIRZO, R., HUBER-SANWALD, E., HUENNEKE, LF., JACKSON, RB., KINZIG, A., LEEMANS, R., LODGE, DM., MOONEY, HA., OESTERHELD, MI., POFF, NL., SYKES, MT., WALKER, BH., WALKER, M. and WALL, DH., 2000. Global biodiversity scenarios for the year 2100 . Science, vol. 287, p. 1770-1774.

SCHERER-LORENZEN, M., BONILLA, LJ. and POTVIN, C., 2007. Tree species richness affects litter production and decomposition rates in a tropical biodiversity experiment. Oikos, vol. 116, p. 2108-2124. http://dx.doi.org/10.1111/j.2007.00301299.16065.x

SCHULZE, E-D., 2000. Climate Change: Managing Forests After Kyoto. Science, vol. 289, no. 5487, p. 2058-2059. PMid:11032555. http://dx.doi.org/10.1126/science.289.5487.2058

SIMAS, F., SCHAEFER, C., FERNANDES FILHO, E., CHAGAS, A., and BRANDAO, P., 2005. Chemistry, mineralogy and micropedology of highland soils on crystalline rocks of Serra da Mantiqueira, southeastern Brazil. Geoderma, vol. 125, no. 3-4, p. 187-201. http://dx.doi.org/10.1016/j.geoderma.2004.07.013

SMITH, MD. and KNAPP, AK., 2003. Dominant species maintain ecosystem function with non-random species loss. Ecology Letters, vol. 6, p. 509-517. http://dx.doi.org/10.1046/j.14610248.2003.00454.x

SOUSA NETO, E., CARMO, JB., KELLER, M., MARTINS, SC., ALVES, LF., VIEIRA, SA., PICCOLO, MC., CAMARGO, P., COUTO, HTZ., JOLY, CA. and MARTINELLI, LA., 2011. Soil-atmosphere exchange of nitrous oxide, methane and carbon dioxide in a gradient of elevation in the coastal Brazilian Atlantic forest. Biogeosciences, vol. 8, no. 3, p. 733-742.

SOUZA, PA., MELLO, WZ., MALDONADO, J., EVANGELISTA, H., 2006 Composição química da chuva e aporte atmosférico na Ilha Grande, RJ. Quimica Nova, vol. 29, no. 3, p. 471-476.

TABARELli, M., AGUIAR, AV., GIRÃO, LC., PERES, CA. and LOPES, AV., 2010. Effects of pioneer tree species hyperabundance on forest fragments in northeastern Brazil. Conservation Biology, vol. 24, p. 1654-1663. PMid:20497203. http://dx.doi.org/10.1111/j.1523-1739.2010.01529.x

TABARELLI, M., DA SILVA, JC. and GASCON, C., 2004. Forest fragmentation, synergisms and the impoverishment of neotropical forests. Biodiversity and Conservation, vol. 13, p. 1419-1425. http://dx.doi.org/10.1023/B:BIOC.0000019398.36045.1b

TILMAN, D., LEHMAN, CL. and THOMSON, KT., 1997. Plant diversity and ecosystem productivity: Theoretical considerations. Ecology, vol. 94, p. 1857-1861.

TRUMBORE, SE., DAVIDSON, EA., CAMARGO, PB., NEPSTAD, DC. and MARTINELLI, LA., 1995. Belowground cycling of carbon in forests and pastures of eastern Amazonia. Global Biogeochemical Cycles, vol. 9, no. 4, p. 515-528. http:// dx.doi.org/10.1029/95GB02148

VIEIRA, AS., ALVES, LF., DUARTE-NETO, PJ., MARTINS, SC., VEIGA, LG., SCARANELLO, MA., PICOLLO, MC., CAMARGO, PB., DO CARMO, JB., SOUSA NETO, E., SANTOS, FAM., JOLY, CA. AND MARTINELLI, LA., 2011. Stocks of carbon and nitrogen and partitioning between aboveand belowground pools in the Brazilian coastal Atlantic Forest elevation range. Ecology and Evolution, vol. 1, no. 3, p. 421-434. http://dx.doi.org/10.1002/ece3.41

VILLELA, DM. and PROCTOR, J., 2002. Leaf litter decomposition and monodominance in the Peltogyne forest of Maraci Island, Brazill. Biotropica, vol. 34, no. 3, p. 334-347.

VILLELA, DM., NASCIMENTO, MT., ARAGÃO, LE. and GAMA, DM., 2006. Effect of selective logging on forest structure and nutrient cycling in a seasonally dry Brazilian Atlantic forest. Journal of Biogeography, vol. 33, p. 506-516. http://dx.doi. org/10.1111/j.1365-2699.2005.01453.x

VILLELA, DM., ARAGÃO, LEOC., GAMA, DM., NASCIMENTO, MT. and REZENDE, CE., 1998. Effect of selective logging on litter production and decomposition in an Atlantic forest, RJ, Brazil. In Anais do IV Simpósio de Ecossistemas Brasileiros, 1998. Águas de Lindóia: ACIESP. p. 253-261.

VITOUSEK, PM. 2004. Nutrient cycling and limitation: Hawai' $\mathrm{i}$ as a model system. Princeton: Princeton University Press. 223 p.

VITOUSEK, PM., MOONEY, HA., LUBCHENCO, J. and MELILLO, JM., 1997. Human domination of earth's ecosystems. Science, vol. 277, p. 494-499. http://dx.doi.org/10.1126/ science.277.5325.494

WAGAI, R., MAYER, L., KITAYAMA, K. and KNICKER, H., 2008. Climate and parent material controls on organic matter storage in surface soils: A three-pool, density-separation approach. Geoderma, vol. 147, no. 1-2, p. 23-33. http://dx.doi.org/10.1016/j. geoderma.2008.07.010

WRIGHT, IJ., REICH, PB., WESTOBY, M., ACKERLY, DD., BARUCH, Z., BONGERS, F., CAVENDER-BARES, J., CHAPIN, T., CORNELISSEN, JHC., DIEMER, M., FLEXAS, J., GARNIER, E., GROOM, PK., GULIAS, J., HIKOSAKA, K., LAMONT, BB., LEE, T., LEE, W., LUSK, C., MIDGLEY, JJ., NAVAS, M-L., NIINEMETS, U., OLEKSYN, J., OSADA, N., POORTER, H., POOT, P., PRIOR, L., PYANKOV, VI., ROUMET, C., THOMAS, SC., TJOELKER, MG., VENEKLAAS, E. and VILLAR, R., 2004. The worldwide leaf economics spectrum. Nature, vol. 428, p. 821-827.

WU, Z., DIJKSTRA, P., KOCH, GW., PEÑUELAS, J., and HUNGATE, BA., 2011. Responses of terrestrial ecosystems to temperature and precipitation change: a meta-analysis of experimental manipulation. Global Change Biology, vol. 17, no. 2, p. 927-942. http://dx.doi.org/10.1111/j.1365-2486.2010.02302.x 